\title{
Evaluation of Red Cell Transfusion Effects on Tissue Oxigenation, Based on Blood Lactate Levels As Sensitive Indicator of Tissue Oxygenation
}

\author{
M. Lordian Nunci ${ }^{1}$, Ilir Ohri Chef ${ }^{2}$, Edi Grabocka ${ }^{3}$ \\ ${ }^{1}$ MD.Sc, Department of Anestheosiology and Intensive Care, University Hospital "Mother Teresa", Rr "Dibres"372 Tirane, Albania \\ ${ }^{2}$ Assistant Professor, Department of Anesthesiology and Intensive Care, University Hospital “Mother Teresa", Rr”Dibres”372 Tirane, \\ Albania
}

${ }^{3}$ MD.PhD, Department of Farmacology, University Hospital “Mother Teresa”, Rr "Dibres”372 Tirane, Albania

\begin{abstract}
Purpose: Evaluation of red cell transfusion effects on tissue oxygenation, by measuring blood lactate levels before and after hemotransfusion. Blood lactate levels are suggested as sensitive parameter to evaluate tissue oxigenation. The aim of this study was to verify the efficiency of hemotransfusions that were performed on patients in intensive care based on lactate level. Studv Design: Prospective observational. Methods: In this prospective observational study on (n-59 patients) who considered that required red cell transfusion.(the patients more that 25 point according to APACHE II-score were excluded).We monitor vital signs (BP, HR) at admission and also was strictly observed lactate level and hemoglobin level at admission before red cell transfusion (pre T), two hours after transfusion ( $2 \mathrm{~h}$ post $\mathrm{T})$ and 24 hours after (24 h post $\mathrm{T}$ with or no any another red cell transfusion). At first the patients group based at hemoglobin level, Group Ia with $\mathrm{Hb}<8 \mathrm{~g} / \mathrm{dl}$ and Group IIb with $\mathrm{Hb} \geq 8 \mathrm{~g} / \mathrm{dl}$. After that the patients group again based at lactate level, Group Ic lactat level $\geq 2$, 4 and Group IId lactate level <2, 4. Results: Comparison between group Ia and group IIb as belongs hemoglobin level demonstrate significance only at admission pre $T$ and lost significance at $2 \mathrm{~h}$ post $\mathrm{T}$ and $24 \mathrm{~h}$ post $\mathrm{T}$, at the other hand differences between group Ic and gropIId as belongs hemoglobin level stay significant at pre $T, 2 h$ post $T$ and $24 h$ post $T$. Conclusions: Statistical significant evaluation $(p<0,05)$ between above mentioned groups shown that lactate level are very sensitive indicator in measuration of tissue oxygenation.. Another important finding was significant high mortality and morbidity at patient group with lactate level $\geq 2,5$.
\end{abstract}

Keywords: red cell transfusion, lactat level, hemoglobin level, oxygenation, anemia.

\section{Introduction}

Anemia is a common finding in patients admitted to the ICU.[25] Studies have shown that $77 \%$ of these patients present anemia during their hospital stay, and more than one third of them end up receiving a red blood cell transfusion. Anemia is secondary to multiple factors. In addition to blood loss provoked by evident bleedings, including iatrogenic anemia, which is caused by collection of blood samples for exams, invasive procedures; nutrition failure; hemolytic; occult blood loss; and endocrine, renal or hepatic system alterations can also lead to a decrease in erythropoietin release, which causes a decreases erythropoiesis. $[1,2]$

Thus, red blood cell transfusion has been often used on patients admitted to ICU. Two studies assessed the incidence of anemia and the use of blood transfusion in Europe and the United States. The European study has shown a transfusion rate of $37 \%$ during the ICU stay, whereas the American study shows that about $44 \%$ of ICU patients underwent transfusion. The mean pretransfusion hemoglobin $(\mathrm{Hb})$ values were $8.4 \mathrm{~g} / \mathrm{dL}$ and $8.6 \mathrm{~g} / \mathrm{dL}$, respectively. However, both studies show that transfusion was associated with a worse prognosis[4, 5]. Moreover, blood transfusion has exhibited several adverse effects that must be assessed when deciding whether to use it. Complications are described in about $20 \%$ of transfusions[6] and can be classified as infectious and noninfectious. Among the infectious complications are the transmission of agents, such as hepatitis B and C virus, HIV, cytomegalovirus, and human T cell lymphotropic virus HTLV, as well as the risk of Chagas and syphilis transmission, among others. The noninfectious complications are related to concomitant transfusions of leucocytes, such as fever, alloimmunization, refractoriness to platelet transfusion, acute lung injury, and immunossupression.[7, 8] A retrospective study has shown that blood transfusion was related to a greater rate of hospital infection[10]. Other undesirable effects caused by the use of blood-derived substances are lung edema due to hypervolemia, hypothermia, coagulopathies, and toxicity due to citrate. [9].

Thus, blood transfusion has poses a difficult problem in ICUs, and there are still many controversial aspects related to its benefits, as well as to the risks of keeping lower levels of $\mathrm{Hb}$ in patients. In a recent study, Hébert et al.[11] did not find benefits related to keeping $\mathrm{Hb}$ between 10 and $12 \mathrm{~g} / \mathrm{dL}$, when compared to a group with $\mathrm{Hb}$ between 7 and $9 \mathrm{~g} / \mathrm{dL}$, in ICU patients. However, when the subgroup of patients with previous heart disease was analyzed, the restrictive strategy was associated with an increased death risk in these patients.

For all above mentioned factor, we attempt in our study to find sensitive indicator, which can improve our judgment for indications of blood transfusions. 
International Journal of Science and Research (IJSR)

ISSN (Online): 2319-7064

Index Copernicus Value (2013): 6.14 | Impact Factor (2014): 5.611

\section{Material and Methods}

A prospective observational analytic study was conducted in 15 ICU bed at University Hospital Center of Tirana"Mother Theresa"between January 2012-January 2014.(Study area).

Throughout this period, consecutive patients aged $>18$ years admitted to the polyvalent (medical and surgical) ICU were enrolled in this study. We excluded from the study: pregnant women, moribond patients, patients pointed $>24$ as APACHE II score. (Exclude criteria).

We recorded demographic variables (age sex), admission diagnosis, preexsiting conditions as comorbidities: cardiac diseases, neurological diseases, pulmonary diseases, gastrointestinal diseases, endocrinol ogical diseases, postoperative conditions and laboratory value. To deterninate the influence of severity of illness on the ICU mortality rates, we evaluated the severity of illness using the Acute Physiological and Chronic Health Evaluation (APACHE II) within the first 1 hours of ICU admission. Consciously we excluded the patients evaluated more that 24 point as APACHE score, because according to literature at the extreme cases, lactat level are missing somewhat accuracy as indicator of tissue oxygenation.

\section{Study Variables}

We used two main outcome variables hemoglobin level and lactat level. Monitoring of this two variables was done at admission time, hemoglobin an lactate level pre hemotransfusion (pre T).Two hours after hemotransfusion( $2 \mathrm{~h}$ post $\mathrm{T}$ ) and 24 hours after the first hemotransfusion $(24 \mathrm{~h}$ post $\mathrm{T})$ notwithstanding the fact wether the patient was hemotrasfusioned two or more time or anymore. Also we monitoried some vital signs at admission time like sistolic blood pressure SBP, heart rate $\mathrm{HR}$, oxygen saturation $\mathrm{SaO}_{2}$, hematocrit level Hct, red cell number Rcn, base exes BE, also unit blood pack, infection, morbidity and mortality. Patients were grouped first based on hemoglobin level. Group $\mathrm{Ia} \mathrm{Hb}<8 \mathrm{gr} / \mathrm{dl}$ and Group $\mathrm{IIb} \mathrm{Hb}$ $\geq 8 \mathrm{gr} / \mathrm{dl}$ and again patient regrouped based on lactate level, Group Ic lactat $\geq 2,4 \mathrm{mmol} / 1$ and Group IId lactat $<2$, $4 \mathrm{mmol} / 1$. None strategy or protocol was used for hemotransfusion trigger. The hemotransfusion decision ruled from judgment of shift doctor. None discrimination was ruled as belongs diagnosis. Table I presents diagnosis of enrolled patients.

\section{Table I}

\begin{tabular}{|c|c|}
\hline Diagnosis & $\mathrm{Nr}$ \\
\hline Gastritis & 6 \\
\hline Duoden Ulcus & 14 \\
\hline Ventricular Ulcus & 7 \\
\hline Esophagal varicose vein & 8 \\
\hline Ventricular Neoformation & 8 \\
\hline Papilocarcinoma vesica urinaris & 1 \\
\hline Hemophillae & 2 \\
\hline Macroscopic Hematuria & 2 \\
\hline Retroperitoneal Hematomae & 2 \\
\hline Colon Neoformation & 1 \\
\hline Pancreatitis & 1 \\
\hline Chronic renal failure & 1 \\
\hline Chronic Anemia & 2 \\
\hline Pancreas Neoformation & 1 \\
\hline Rectoraghia & 3 \\
\hline
\end{tabular}

Statistical analysis performed on above mentioned groups, gave as some important findings.

\section{Data Analysis}

The supervisors checked all patient file at the end of each data collection day to ensure the accuracy. Before starting the analysis, each variable was checked for abnormal values or different respondent rates. The data were coded and analyzed using SPSS statistical software (SPSS 16.0 Chicago, Illinois, USA.) Summary statistics such as means, standard deviations (SD), frequencies and proportions, were used to summarize variables. Chi-square tests were used to identify associations between categorical variables with $\mathrm{P}$ value less than 0.05 as the significance level. Logistic regression analysis was conducted to determine the significant predictors of outcomes.

\section{Ethical Considerations}

The Albanian Ethical Committee reviewed and approved the study protocol. Following ethical approval, permission to conduct data collection was obtained from the District Public Health Directories of Tirana. Informed verbal consents were obtained from all patients or familiars who agreed to participate in the interviews.

\section{Results}

Total number of enrolled patients was 59.The mean age of respondents was $57,05(\mathrm{SD} \pm 18,56)$ years, from which 20 were women and 39 men. As we mentioned above the evaluation of severity of illness was conducted, by using the APACHE II score within the first 1 hours of ICU admission and the average score was $11,17(\mathrm{SD} \pm 5,10)$. Statistical analysis performed on some vital signs at admission time showed the below results: Systolic blood pressure 112, $78(\mathrm{SD} \pm 29,05)$, Heart rate $100,54(\mathrm{SD} \pm 19, \quad 96)$, $\mathrm{SaO}^{2} 95 \%(\mathrm{SD} \pm 0,1)$, Hematocrit $23,2 \%(\mathrm{SD} \pm 3,4 \%)$, Red cell number(at admission time)2, $69 \times 10^{6}(\mathrm{SD} \pm 0,49)$. The number of blood pack used for patient during this study was 2, $05(\mathrm{SD} \pm 1,28)$ with average indwelling at ICU 3, $83(\mathrm{SD} \pm 2,46)$. Also the calculation of mortality results 15 , $30 \%$ and infections complication 15, $30 \%$. (SIRS-Systemic inflammatory response syndrome).

Table 2: below show our statistical analysis.

\begin{tabular}{|c|c|c|}
\hline & mean & $\mathrm{SD} \pm$ \\
\hline Age & 57,05 & 18,56 \\
\hline Sex W/M & 20 & 39 \\
\hline Apache II Score & 11,17 & 5,10 \\
\hline SBP ad. T* & 112,78 & 29,05 \\
\hline Hr ad.T & 100,54 & 19,96 \\
\hline Hct ad.T & $23,2 \%$ & 3,4 \\
\hline SaO' ad.T & $95 \%$ & 0,01 \\
\hline BE ad.T & $-3,32$ & 3,28 \\
\hline Blood pack & 2,05 & 1,28 \\
\hline Hb pre HT & 7,11 & 1,10 \\
\hline Hb 2h post HT & 7,66 & 1,06 \\
\hline Hb 24h post HT & 8,35 & 0,65 \\
\hline Lactat pre HT & 2,41 & 1,40 \\
\hline Lactat 2h post HT & 2,06 & 1,22 \\
\hline Lactat 24h post HT & 1,83 & 1,08 \\
\hline Infection & 9 from 59 & $15.30 \%$ \\
\hline Morbidity & 3,83 & 2,46 \\
\hline Mortality & 9 from 59 & $15.30 \%$ \\
\hline
\end{tabular}




\section{International Journal of Science and Research (IJSR) \\ ISSN (Online): 2319-7064}

Index Copernicus Value (2013): 6.14 | Impact Factor (2014): 5.611

(*SBP ad T- sistolic blood presure at admission time, $\mathrm{Hr}$ heart rate)

(*Hb pre HT- hemoglobin level before hemotransfusion, $\mathrm{Hb}$ $2 h$ post HT- 2 hours after hemotransfusion)

As mentioned above comparison was done between Group Ia $\mathrm{Hb}<8 \mathrm{gr} / \mathrm{dl}$ and Group $\mathrm{IIb} \mathrm{Hb} \geq 8 \mathrm{gr} / \mathrm{dl}$ where findings shown that Group IIb characterized from figures significantly higher on sistolic blood pressure, hematrocrit, red cell number meanwhile Group Ia characterized from level significantly higher on laktat level which made without significant only 24 hours after hem transfusion. Also differences have between the numbers of blood packet transfused. Following figures illustrate.

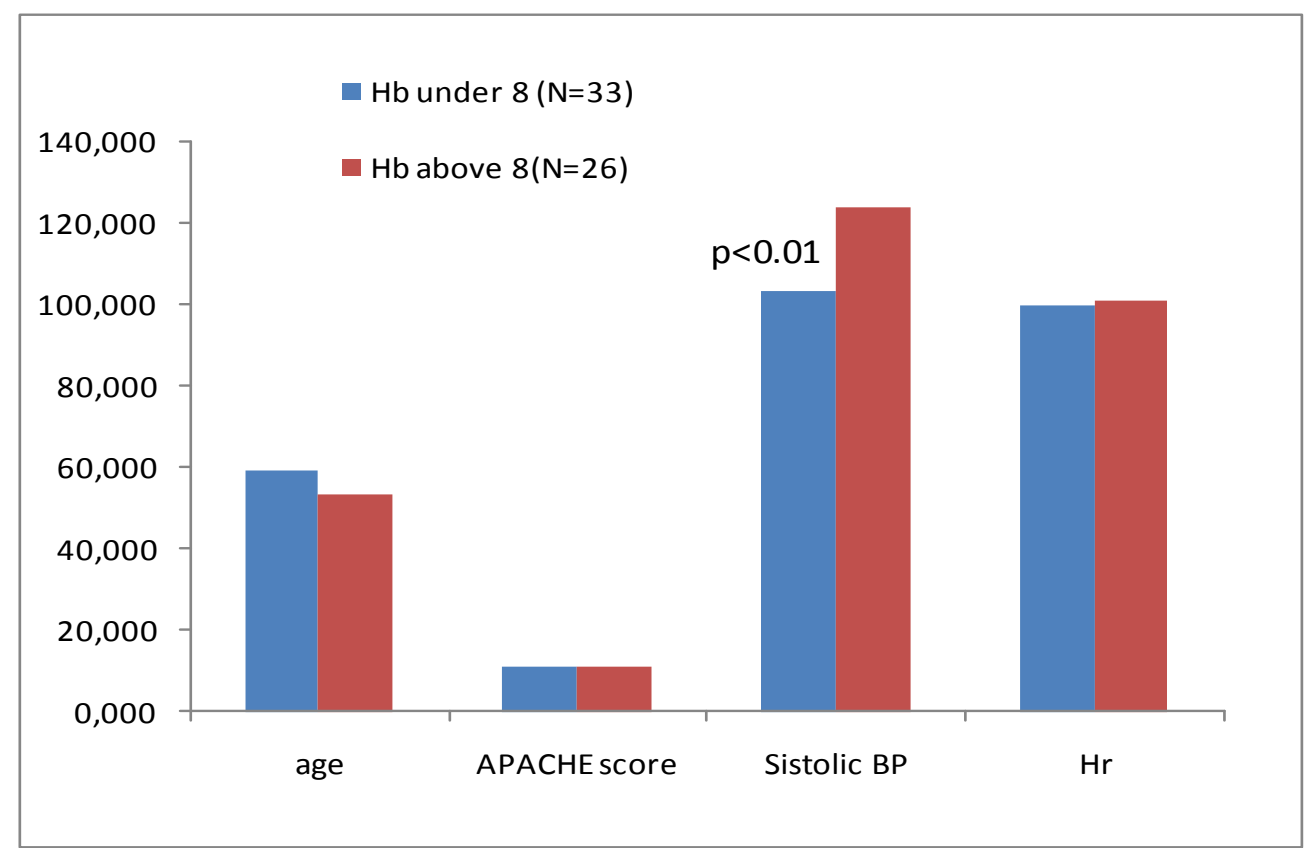

Figure 1

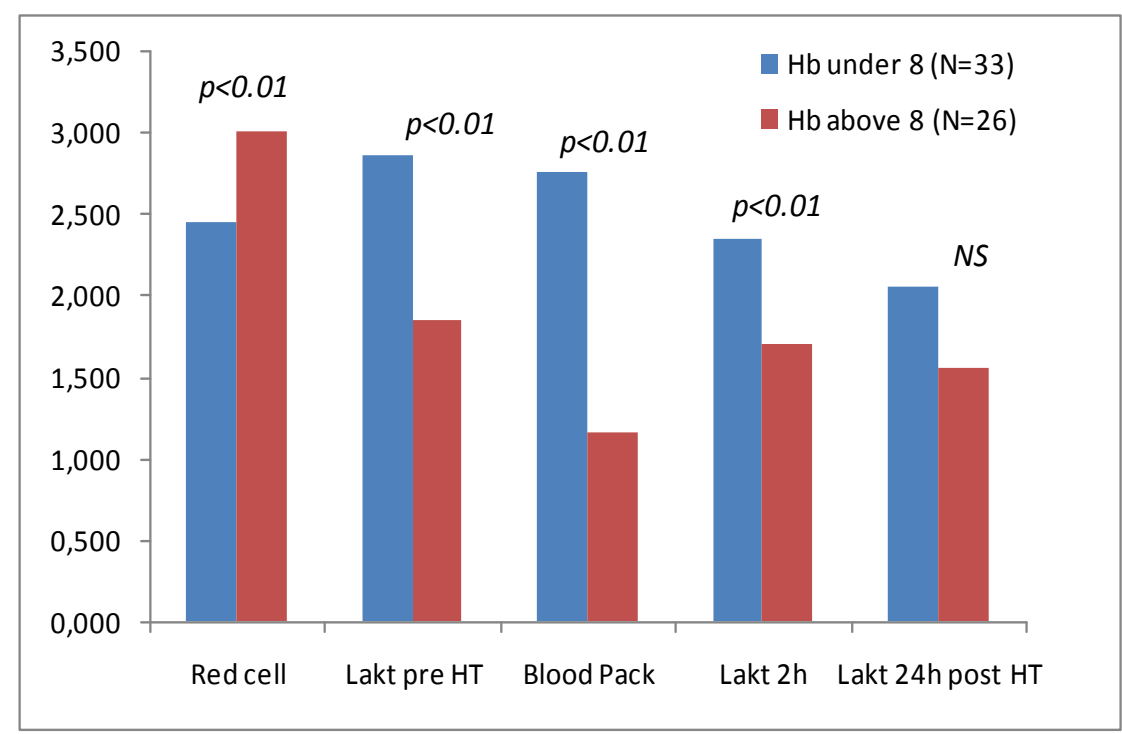

Figure 2 


\section{International Journal of Science and Research (IJSR) \\ ISSN (Online): 2319-7064}

Index Copernicus Value (2013): 6.14 | Impact Factor (2014): 5.611

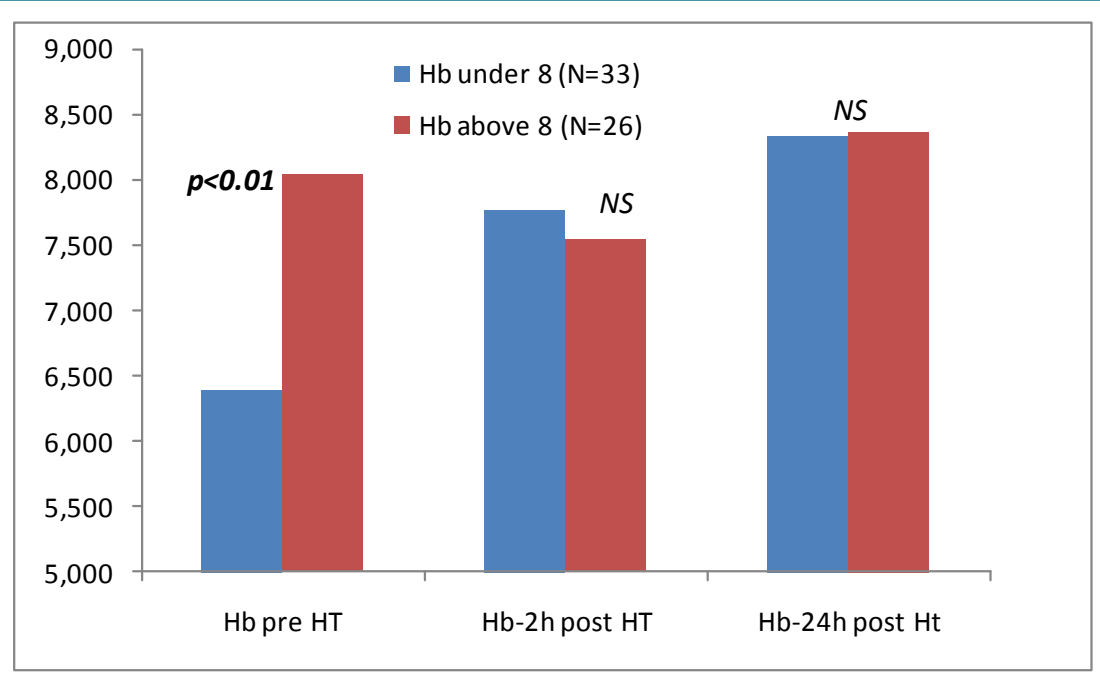

Figure 3

No differences were find between two groups as belongs age, APACHE score, heart rate and no significant on indwelling. The significant differences on hemoglobin level at admission time $(\mathrm{Hb}$ pre $\mathrm{HT})$ lose it $2 \mathrm{~h}$ after hemotransfusion and of course also after $24 \mathrm{~h}(\mathrm{Hb} 2 \mathrm{~h}$ post HT and $\mathrm{Hb} 24 \mathrm{~h}$ post HT).Mortality 3 patients $9 \%$ at Group Ia versus 6 patients $23 \%$ at Group $\operatorname{IIb}(\mathrm{p}=0.14)$ showed differences at percentage but not on statistical analysis.

On the other hand statistical analysis between Group $\mathrm{Ib}$ lactate level $\geq 2,4 \mathrm{mmol} / 1$ and Group IIc lactate level show that Group Ib chararacterized from value significant higher on age, APACHE score, heart rate and lower value of sistolic blood pressure, hematocrit, base exes, red cell number at admission time. Number of blood pack at first group was significant higher compare with Group IIc. At Group Ic lactat level stay again significant 2 hours and 24 hours after hemotransfusion, the same thing we can say also for differences at hemoglobin level 2 and 24 hours after hemotransfusion. Indwelling was significant higher at Group Ic. Changing Group Ia and Group IIb at GrIb vs. GrIIc mortality was significant higher at Group Ic. Following figures illustrate our results.

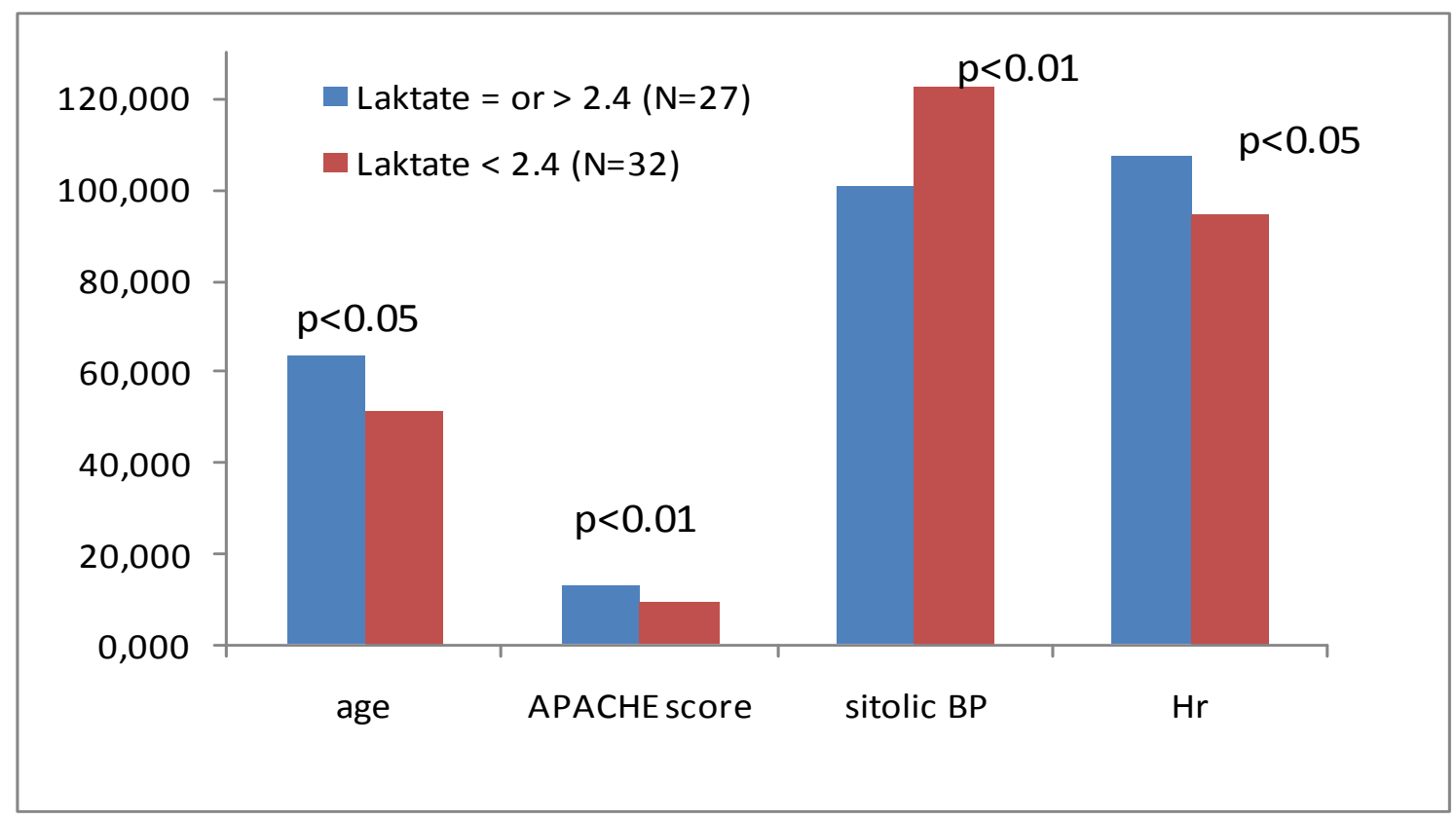

Figure 4 


\section{International Journal of Science and Research (IJSR) \\ ISSN (Online): 2319-7064}

Index Copernicus Value (2013): 6.14 | Impact Factor (2014): 5.611

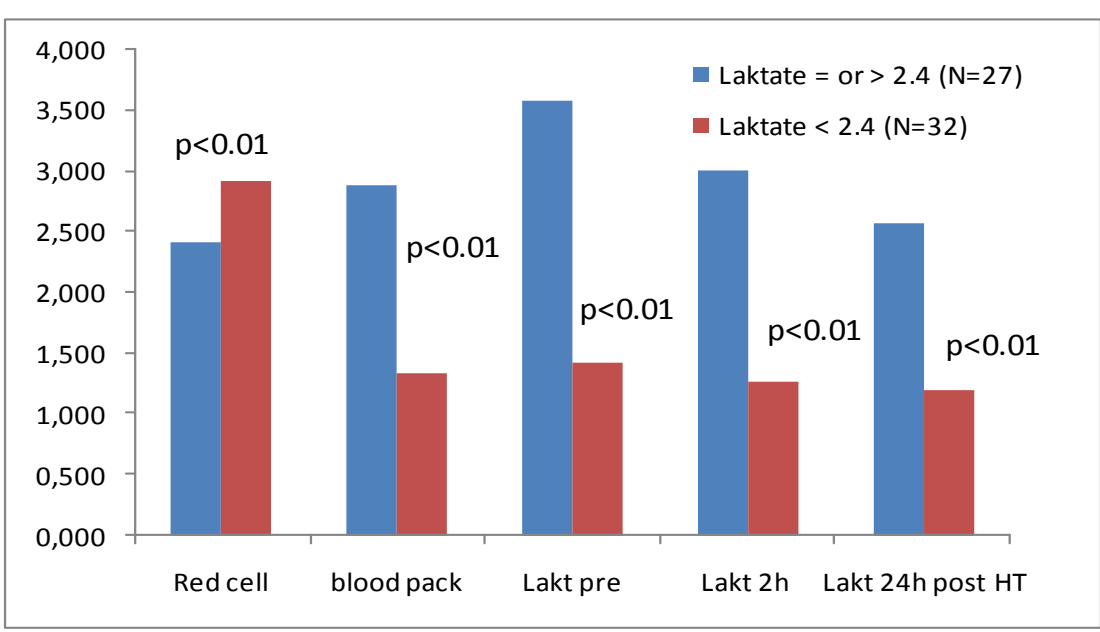

Figure 5

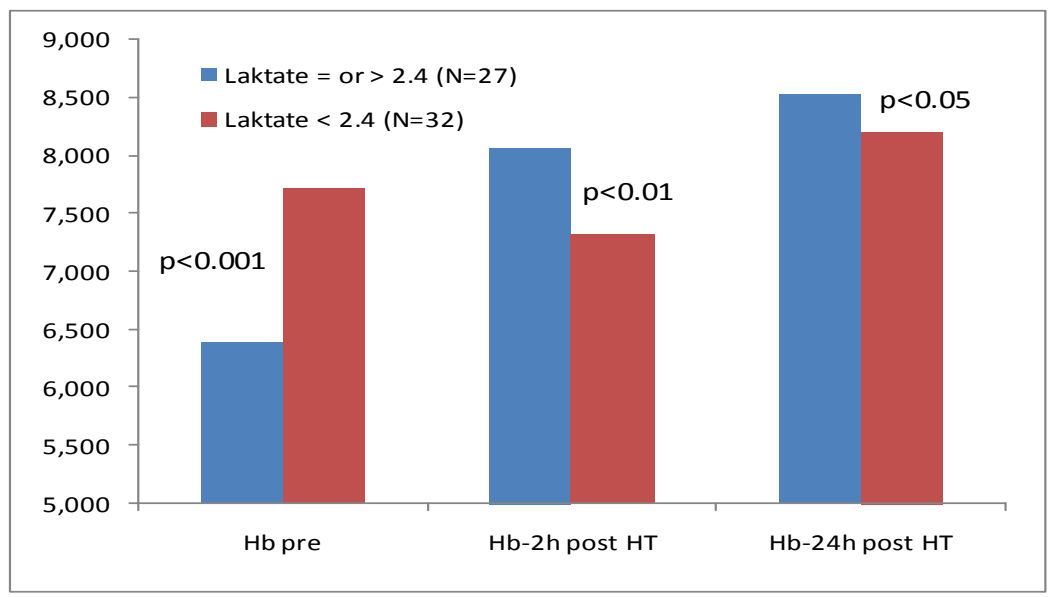

Figure 6

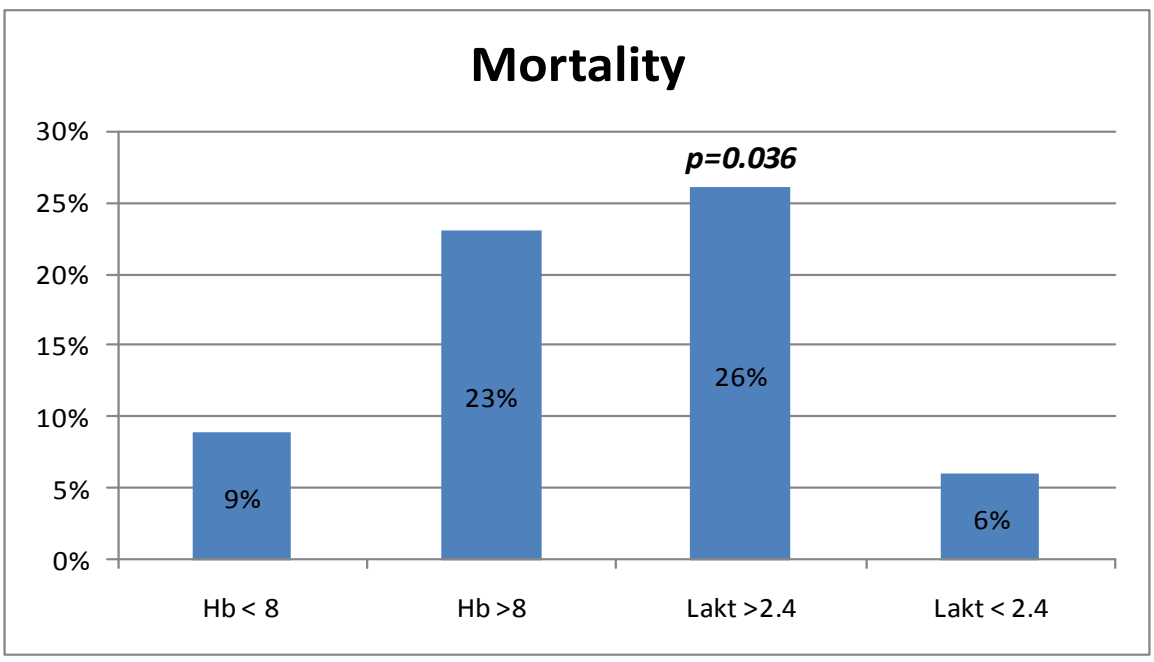

Figure 7

\section{Discussion}

From almost 200 years we have started to use blood transfusion. Today we have the ability to know the big number of complications infectious on noninfectious related with blood transfusion. But, why we continuing to use it, with such big risk of undesirable adverse effects? The simple response is, we need an oxygen transporter with final target improving tissue oxygenation, but until today no other compound can performed it. A numerous studies promote restrictive strategy on blood transfusion with aim not only avoiding complications but also announce, that liberal strategy can not improve outcomes and surviving rate. Hébert et al.[11] reported that a restrictive strategy in terms of blood transfusions was adequate, with a mortality rate lower than that observed in the group that received more transfusions. In this line, our study attempts to elaborate the accuracy of lactate level on tissue oxygenation.

Truly the major number of intensives doctors in Albania trigger hemotransfusion mainly based on hemoglobin level

\section{Volume 4 Issue 11, November 2015}




\section{International Journal of Science and Research (IJSR) \\ ISSN (Online): 2319-7064}

Index Copernicus Value (2013): 6.14 | Impact Factor (2014): 5.611

and vital signs. Traditional vital signs at triage are used as surrogate markers by their ability to indirectly measure blood lose volume. In our study Figure 1 . show that between Group Ia vs. Group IIb at admission time has not significant difference on vital signs as age, heart rate, apache score but only sistolic BP.So we can conclude that some vital signs has low sensitivity on evaluation of blood lose or tissue oxygenation. At similar study Paladino at al[26] shows superiority of lactat level vs vital sings in differentiating major from minor injury in trauma patients with normal vital signs. Meanwhile statistical changes based on lactat level appear significant between two groups not only at admission time but also 2 hours after hemotransfusion and lose importance only 24 hours after hemotransfusion. On the other hand important changes between above mentioned groups linked with hemoglobine level are significant only at admission time and no more.

But, what happen when we regroup those patient base on lactat level? As we can see Figure 4 shows that exist significant difference between Group Ic vs Group IId as belong vital signs like age, apache score, sistolic blood presure and heart rate. Conclusions could be that, when we evaluate tissue oxygenation primarily based on lactat level the sensitivity of vital signs is also higher.

Patients on extreme conditions often can suffer from oxygen imbalance between supply and demand[28]. The comparison between Figure 2 and 3 versus Figure 5 and 6 tell us, despite the fact of hemoglobin level increase, improving of tissue oxygen was not going parallel with hemoglobin increasing. Lorente at al[29] reported that sistemic oxygen content $\left(\mathrm{VO}_{2}\right)$ has no increasing, at septic patients with nonivasive oxygenation despite the hemotransfusions increased the hemoglobin level from $9,6 \mathrm{gr} / \mathrm{dl}$ to $11,6 \mathrm{gr} / \mathrm{dl}$. The same results was reported from similar studies [30].

At last our analysis about mortality at four groups Figure 7 shows the highest mortality rate at Group Ic with $26 \%$ mortality and the best survival rate Group IId only with 6\% mortality. Meanwhile Group Ia mortality rate 9\% and Group IIb 23\%. Statistical significance was seen only at Group Ic $(\mathrm{p}=0,036)$. Those findings allow us to say that high level of hemoglobin or liberal strategy of hemotransfusion, do not improve the survivance rate, on the other hand lactat level are not only best marker of tissue oxygenation but also are a good predictor of survival prognosis.

\section{Conclusion}

The results of our study demonstrated that lactat levels are sensitive and accurate marker of tissue oxygenation. Amission lactat level and serial lactat measurements should be used to quickly identify tissue hipooxygenation. This strong parameter will improve our judgment on hemotransfusion trigger. Restrictive strategy will be more logical and justified than unnecessary hemotransfusions that will expose patients in front of numerous risks. Also in this prospective observial study lactat level shows to be a good predictor of survival.

\section{Acknowledgement}

Not available.

\section{Conflict of Interest Disclosure}

The authors have no conflict of interest.

\section{References}

[1] Vincent JL, Sakr Y, Creuteur J. Anemia in the intensive care unit. Can J Anesth. 2003;50(6):S53-9

[2] Nguyen BV, Bita DP, Mélot C, Vincent JL. Time course of hemoglobin concentrations in nonbleeding intensive care unit patients. Crit Care Med. 2003;31(2):406-10.

[3] Faquin WC, Scheneider TJ, Goldberg MA. Effect of inflammatory cytokines on hypoxia induced erythropoietin production. Blood. 1992;79(8):1887-94

[4] Vincent JL, Baron JF, Rheinhart K, Gattinoni L, Thijs L, Webb A, et al. Anemia and blood transfusion in critically ill patients. JAMA. 2002;288(12):1499-07

[5] Corwin HL, Gettinger A, Pearl RG, Fink MP, Levy MM, Abraham E, et al. The CRIT Study: Anemia and blood transfusion in the critically ill current clinical practice in the United States. Crit Care Med. 2004;32(1):39-52

[6] Walker RH. Transfusions risks. Am J Clin Pathol. 1987;88(3):374-78

[7] Perrota PL, Snyder PL. Non-infectious complications of transfusion therapy. Blood Rev. 2001;15(2):69-83.

[8] Mercuriali F, Inghilleri G. Transfusion Risks and limitations. Minerva Anestesiol. 1999;65(5):286-92

[9] Goodnough LT. Risks of blood transfusion. Crit Care Med. 2003;31(12):S678-86.

[10] Taylor RW, Manganaro L, O’brien J, Trottier SJ, Parkar N, Veremakis C, et al. Impact of allogenic packed red blood cell transfusion on nosocomial infection rates in the critically ill patient. Crit Care Med. 2002;30(10):2249-54 27

[11] Hébert PC, Wells G, Blajchman MA, Marshall J, Martin C, Pagliarello G, et al. A multicenter randomized controlled clinical trial of transfusion requirements in critical care. $\mathrm{N}$ Engl $\mathrm{J}$ Med. 1999;340(6):409-17

[12] Task Force of the American College of Critical Care Medicine: Practice parameters for hemodynamic support of sepsis in adult patients in sepsis. Crit Care Med. 1999;27(3):639-60.

[13] Rivers EP, Ander DS, Powell D. Central venous oxygen saturation monitoring in the critically ill patient. Curr Opin Crit Care. 2001;7(3):204-11.

[14] Bakker J. Blood lactate levels. Curr Opin Crit Care. 1999;5(3):234-39.

[15] 249. Weg JG. Oxygen transport in adult respiratory distress syndrome and other acute circulatory problems: relationship of oxygen delivery and oxygen consumption. Crit Care Med. 1991;19(5):650-57.

[16] Hébert PC, Tinmouth A, Corwin H. Anemia and red cell transfusion in critically ill patients. Crit Care Med. 2003;31(12):S672-77. 


\section{International Journal of Science and Research (IJSR) \\ ISSN (Online): 2319-7064}

Index Copernicus Value (2013): 6.14 | Impact Factor (2014): 5.611

[17] Marik PE, Sibbald WJ. Effect of stored-blood transfusion on oxygen delivery on patients with sepsis. JAMA. 1993;269(23):3024-29.

[18] Hammed SM, Aird WC, Cohn M. Oxygen delivery. Crit Care Med. 2003;31(12):S658-67.

[19] Society of Critical Care Medicine Consensus Conference Committee. American College of Chest Physicians / Society of Critical Care Medicine Consensus Conference: Definitions for sepsis and organ failure and guidelines for the use of innovative therapies in sepsis. Crit Care Med. 1992;20(6):864-74.

[20] Rivers EP, Nguyen B, Havstad S, Ressler J, Muzzin A, Knoblich B, et al. Early goal-directed therapy in the treatment of severe sepsis and septic shock. N Engl J Med. 2001;345(19):1368-77.

[21] Fink MP. Cytopathic hypoxia. Mitochondrial dysfunction as mechanisms contributing to organ dysfunction in sepsis. Crit Care Clin. 2001;17(1):21937.

[22] Tem Cate H. Pathophysiology of disseminated intravascular coagulation in sepsis. Crit Care Med. 2000;28(9):S9-11.

[23] Schate M, Fink MP. Red blood physiology in critical illness. Crit Care Med. 2003;31(12):S651-57

[24] Tim C Jansen, Jasper van Bommel, Paul G Mulder, Johannes H Rommes, Selma JM Schieveld and Jan Bakker. The prognostic value of blood lactate levels relative to that of vital sings in the pre-hospital setting, a pilot study.(Critical Care R160 doi:101186/cc7159)

[25] Bruno Franco Mazza; Flávia Ribeiro Machado; Débora Dutra Mazza; Valeria Hassmann. Evaluation of blood transfusion effects on mixed venous oxygen saturation and lactate levels in patients with SIRS/sepsis. Print version ISSN 1807-5932

[26] Lorenzo Paladino, Richard Sinert, David Wallace, Todd Andrson, Kabirr Yadav, Shahrir Zehtabchi.The utility of base deficit and arterial lactate in differrntiatin major from minor injury in trauma patients with normal vital sings.(doi:10.1016/j.resuscitation.2008.01.022

[27] David Bar-Or, KristinM.Salottolo, MPH, AlessandroOrlando, MPH, CharlesW.Mains, MD, Pamel Bourg, Patrick J.Offner.Association Between a Geatric Trauma Resusciaation Protocol Using Venous Lactate Measuarment and Eaarly Trauma Surgenon Involment and Mortality Risk.(doi:101111/jgs.12365)

[28] Friedman G, De Backer D, Shahla M, Vincent JL. Oxygen supply dependency can characterize septic shock. Intens Care Med, 1998; 24: 118-123.

[29] Lorente JA, Landin L, de Pablo R, Renes E, Rodriguez-Diaz R, Liste D. Effects of blood transfusion on oxygen transport variables in severe sepsis. Crit Care Med, 1993; 21: 1312-1318.

[30] Hebert PC. Transfusion requirements in critical care: a multicenter controlled clinical trial. In: Vincent JL, ed. Yearbook of intensive care

\section{Author Profile}

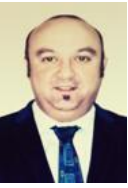

Lordian Nunci graduated as physician in Medicine Faculty of Tirana University on 1997. During 19982002 he stayed as resident near Department of Anesthesiology and Intesive Care. After, he continued working at Intensive Care Unit. In this time he was tried to improve our experience in some filds such as mechanical ventilation, purmonary care and blood transfusion by followed course in some qualified european centers. 